\title{
Potential of Lactobacillus casei Shirota Strain Probiotic Toward Total Cholesterol Levels and Sod Activity in Rat with High Cholesterol Diet
}

\author{
Kiswanti Surya Utami ${ }^{1}$, Chanif Mahdi ${ }^{1}$, Aulanni’am Aulanni'am ${ }^{1,2}$ \\ ${ }^{1}$ Chemistry Department, Faculty of Mathematics and Natural Sciences, Brawijaya University, \\ Malang, Indonesia \\ ${ }^{2}$ Faculty of Veterinary, Brawijaya University, Malang, Indonesia \\ *email: onetykeyko@gmail.com
}

Received July 25, 2017; Accepted November 03, 2017; Available online November 30, 2017

\begin{abstract}
Probiotic of Lactobacillus casei Shirota strain is lactic acid bacteria that have benefits to enhance immunity system, as an antioxidant and has the ability to decrease the cholesterol level. The aim of this study was to determine the potential of Lactobacillus casei Shirota strain probiotic toward total cholesterol decreasing and SOD activity increasing in rats' aorta with a high-cholesterol diet. This study used 25 male rats of Rattus novergicus Wistar strain that will be divided into 5 groups. The $1^{\text {st }}$ group as the negative control, and the $2^{\text {nd }}$ group as positive control. The positive control group was induced by high-cholesterol diet contained quail egg yolk, pure cholesterol, cholic acid and waste oil that were given for 3 weeks. The $3^{\text {rd }}, 4^{\text {th }}$ and $5^{\text {th }}$ group were treated by probiotic Lactobacillus casei Shirota strain with variation dose of $3.6 \times 10^{7}, 7.3 \times 10^{7}$ and $10.9 \times 10^{7}$ cells $/ \mathrm{kg}$ bodyweight/day. The results showed that probiotic of Lactobacillus casei Shirota strain therapy dose of $10.9 \times 10^{7}$ cells/kg bodyweight/day can decrease the total blood cholesterol of rats' serum that were given with high-cholesterol diet of about $32.0 \%$. In addition, the probiotic of Lactobacillus casei Shirota strain therapy also increase the activity of SOD about $50.70 \%$.
\end{abstract}

Keywords: Lactobacillus casei Shirota strain, total cholesterol, superoxide dismutase

\section{INTRODUCTION}

Cardiovascular disease is caused by a disturbance in the heart and blood vessel function that are dangerous to health, the examples of cardiovascular diseases are coronary heart disease and stroke (Rastini, 2010). The cause of these disease is atherosclerosis. The main factors causing atherosclerosis is hypercholesterolemia or high cholesterol levels.

Cholesterol levels in the body can be determined by examining the total cholesterol level in the blood. The total cholesterol levels include of LDL, HDL and triglycerides. Normal total cholesterol levels in humans is $<200 \mathrm{mg} / \mathrm{dL}$. High levels of total cholesterol in the blood can be caused by high cholesterol diet. High cholesterol diet that performed continuously will cause an accumulation of LDL cholesterol in the blood vessels and oxidation of LDL cholesterol (Towil \& Pramono, 2014). In addition, it will produce of free radicals or ROS (Reactive Oxygen Species) in the body.

ROS can be assailed by antioxidant of SOD (Superoxide Dismutase). The activity of SOD can be inhibite by ROS. The high of ROS in the body due to the induction of highcholesterol diet can of cause a decrease in SOD antioxidant activity (Bayatmakoo, Rashtcizadeh, Yaghmaei, Farhoudi, \& Karimi, 2017). SOD activity test is used to determine the resistance of cells against ROS.

Probiotic of Lactobacillus casei Shirota strain a lactic acid bacteria that can improve the health of digestive system. Moreover, these bacteria also have the ability to boost the immune system as well as antioxidant of cholesterol reducer. Probiotic of Lactobacillus casei Shirota strain commonly used in fermented beverages made from milk. Sujono, Bekti, Hikmawan \& Yuananda (2016) goat milk yogurt that used Lactobacillus bulgaricus bacteria can be decresing the levels of total cholesterol by 52,17 mg/dL. Yuniastuti (2004) Fermented milk containing Lactobacillus casei Shirota strain can reduce the total cholesterol level. The ability of each probiotic to decrease the cholesterol may varies, depending on the type of probiotic bacteria used.

The aim of this study is to determine the potential of Lactobacillus casei Shirota strain probiotic with therapeutic dose of $3.6 \times 10^{7}$, $7.3 \times 10^{7}$ and 10.9 x $10^{7}$ cells $/ \mathrm{kg}$ bodyweight/day of male white rats (Rattus norvegicus) that induced by high-cholesterol diet toward total cholesterol decreasing in rats' 
blood serum and SOD activity increasing in rats' aorta with a high-cholesterol diet.

\section{EXPERIMENTAL SECTION}

\section{Material and Instrumentation}

Chemicals used in this study is the probiotic of Lactobacillus casei Shirota strain that commercial, cholic acid (Kasei Tokyo), pure cholesterol (SIGMA), oil, egg yolk of quail, SOD kit (Biovision), BioSiystem S.A Costa Brava 30 kit, phosphate buffer saline (PBS) solution, tris $\mathrm{HCl}$, PBS-tween, $0.9 \%$ sodium chloride, ethanol and distilled water.

The tools used in this study were centrifuges, analytical balance (Mattler Toledo), incubators, sepectrophotometer UVVis (Thermoscintific Genesys 20), bath water, gavage needle, microhematocrit or capillary tubes, Eppendorf tubes, microtube, surgical equipment, vacutainer, mortar, freezer, refrigerator, 96 well microplate, $3 \mathrm{~mL}$ syringe (Terumo), cuvette, mikropipet $100 \mu \mathrm{L}$ and $1000 \mu \mathrm{L}$ (Nichipet EX), microplate reader and Easy Touch GCU to check the blood cholesterol level experimental animals.

\section{Procedure \\ Sample Preparation}

Probiotic of Lactobacillus casei Shirota strain sample stored in the refrigerator (storage conditions temperature $0-10{ }^{\circ} \mathrm{C}$ ). Probiotic bacteria used were Lactobacillus casei Shirota strain. The number of probiotic bacteria is calculated by calculating the total lactic acid bacteria (total LAB).

\section{Preparation of Experimental Animals}

Rats used were 25 white male rats (Rattus norvegicus) weighing 175 -250 grams and age $2-3$ months. Rats were divided into 5 groups: negative control (healthy), positive control (sick) that were given high-cholesterol diet for 3 weeks, and the three treatment groups were given high-cholesterol diet and treated with the probiotic of Lactobacillus casei Shirota strain orally with 3 dose $(3.6 \mathrm{x}$ $10^{7}, 7.3 \times 10^{7}$ and $10.9 \times 10^{7}$ cells $/ \mathrm{kg}$ bodyweight/day) variations therapy. Probiotic of Lactobacillus casei Shirota strain therapy carried out for 2 weeks.

The use of experimental animals which have been approved by the ethical acceptance of UB's Research Commission No. KEP-554UB. High-cholesterol diet that were given consists of $1 \mathrm{~g}$ pure cholesterol, $0.02 \mathrm{~g}$ cholic acid, $1 \mathrm{~g}$ quail egg yolk, and $0.24 \mathrm{~mL}$ oil which has been mixed with pure water to $3 \mathrm{~mL}$. All blood's rats be taken from aortic for blood serum analysis of total cholesterol and abdominal aortic tissue for activity of SOD analysis.

\section{Measurement total cholesterol levels of blood serum}

Total cholesterol levels were determined using BioSiystem S.A Costa Brava 30 kit, with CHOD-PAP method. Each rats' blood was taken $5 \mathrm{~mL}$ then it was centrifuged at 3000 $\mathrm{rpm}$ for $10 \mathrm{~min}$. Afterward, the serum were collected at microtube and it will be added cholesterol kit as much as $1 \mathrm{~mL}$. Sample absorbance was measured using a spectrophotometer at a wavelength of $500 \mathrm{~nm}$.

\section{Measurement of superoxide dismutase (SOD) activity in aortic tissue}

Measurement were started with SOD protein isolation from aortic tissue. Then, SOD activity is determined using SOD Biovision kit. Each sample of solutions were added about 20 $\mu \mathrm{L}$ and $2^{\text {nd }}$ blank, and $20 \mu \mathrm{L}$ of $\mathrm{H}_{2} \mathrm{O}$ were added in $1^{\text {st }}$ blank and $3^{\text {rd }}$ blank. Then they were added by $200 \mu \mathrm{L}$ of WST (Water Soluble Tetrazolium) working solution in each sample. After that, dilution buffer was added about 20 $\mu \mathrm{L}$ in each $2^{\text {nd }}$ blank and $3^{\text {rd }}$ blank. In the other hand, in each sample and $1^{\text {st }}$ blank were added by $20 \mu \mathrm{L}$ of enzyme working solution and all of the mixture were being homogenate. Each mixture was incubated at $37^{\circ} \mathrm{C}$ for 20 minutes. Samples will be measured using a microplate reader with a wavelength of $450 \mathrm{~nm}$.

\section{RESULTS AND DISCUSSION}

\section{Total LAB And Total Cholesterol Levels of Blood Serum}

The quantity of bacteria in probiotic Lactobacillus strain Shirota strain samples determined using Total LAB method which is $7.3 \times 10^{7} \mathrm{CFU} / \mathrm{mL}$. These results are in accordance with the standards of SNI (2009) that the amount of LAB in fermented milk is at least equal to $10^{7}$.

The effective dose of probiotics as hypocholesterolemia treatment are vary widely, depending on the strain used. The range of probiotic used in human $10^{7}-10^{11}$ CFU/day and animals $10^{7}-10^{9}$ CFU/day. Some probiotics have been efficacious in inducing at the lowest levels, while some others require larger quantities to give 
hypokolesterolemia effect (Ooi, Gaik, \& Liong, 2010).

The results showed that probiotic of Lactobacillus casei Shirota strain therapy can reduce the total cholesterol level. The results of statistical analysis were deteremined using One Way ANOVA, and exhibited that probiotic therapy with Lactobacillus casei Shirota strain with variation dose of $3.6 \times 10^{7}, 7.3 \times 10^{7}$ and $10.9 \times 10^{7}$ cells $/ \mathrm{kg}$ bodyweight/day can decrease the total cholesterol levels by based on its extremely significant differences between each treatments $(p<0.01)$. The results of the total cholesterol level can be seen in Figure 1.

Positive control group had a higher total cholesterol levels than the other groups of 81,2 $\mathrm{mg} / \mathrm{dL}$ and an increasing of $69.8 \%$ toward a negative control. Total cholesterol levels in positive control group showed that rats had hypercholesterolemia, because of the total cholesterol levels above the normal range in rats'. Harini \& Astirin (2009) the normal total cholesterol levels in Rattus norvegicus Wistar strain rats is $10-54 \mathrm{mg} / \mathrm{dL}$. This result indicates that the induction of high-cholesterol diet with the feed that contain of of pure cholesterol, cholic acid, quail egg yolk and oil (jelanta) can increase total cholesterol levels of rats.

Increased levels of total cholesterol is influenced by the content of saturated fatty acids and cholesterol that very high in a quail egg yolk and used oil and it completed with the addition of pure cholesterol. The content of cholesterol in eggs quail is $3640 \mathrm{mg} / 100 \mathrm{~g}$ (Dewi, 2009). The used oil (jelantah) have highest total cholesterol levels among coconut oil, curah oil (oil without label) and lard oil, which is $86.20 \mathrm{mg} / \mathrm{dL}$ (Bogoriani \& Ketut, 2015). Feeding $1 \%$ cholesterol for 2 months can increase blood serum cholesterol level of hypercholesterolemia group of rats by $90 \%$ (Wresdiyati, Astawan \& hastanti, 2006).

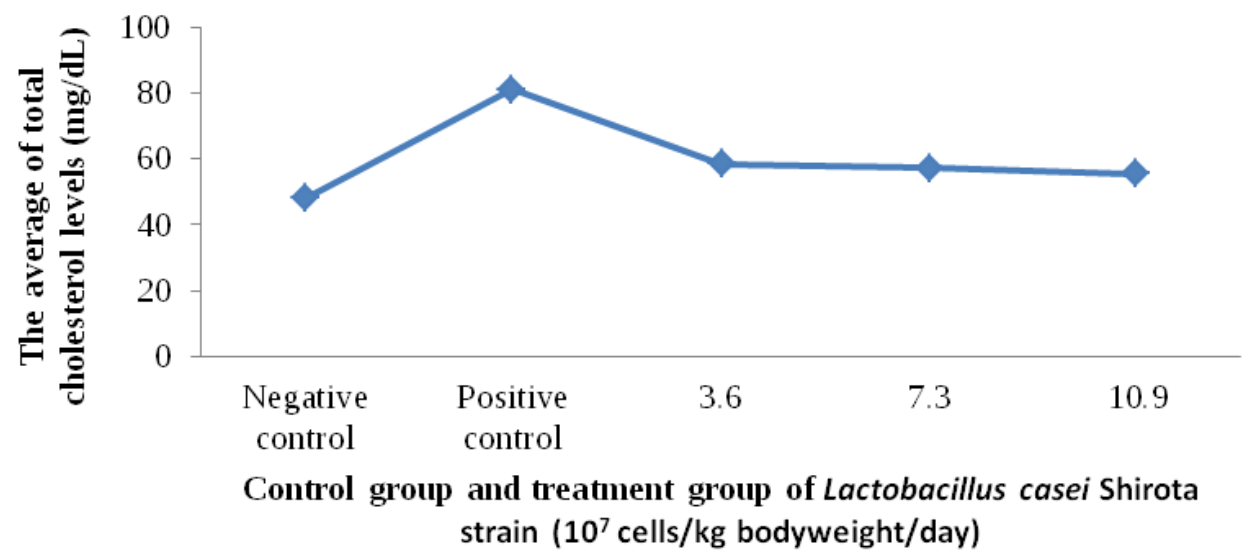

Figure 1. The result of total cholesterol levels after treatmen by probiotic of Lactobacillus casei Shirota strain

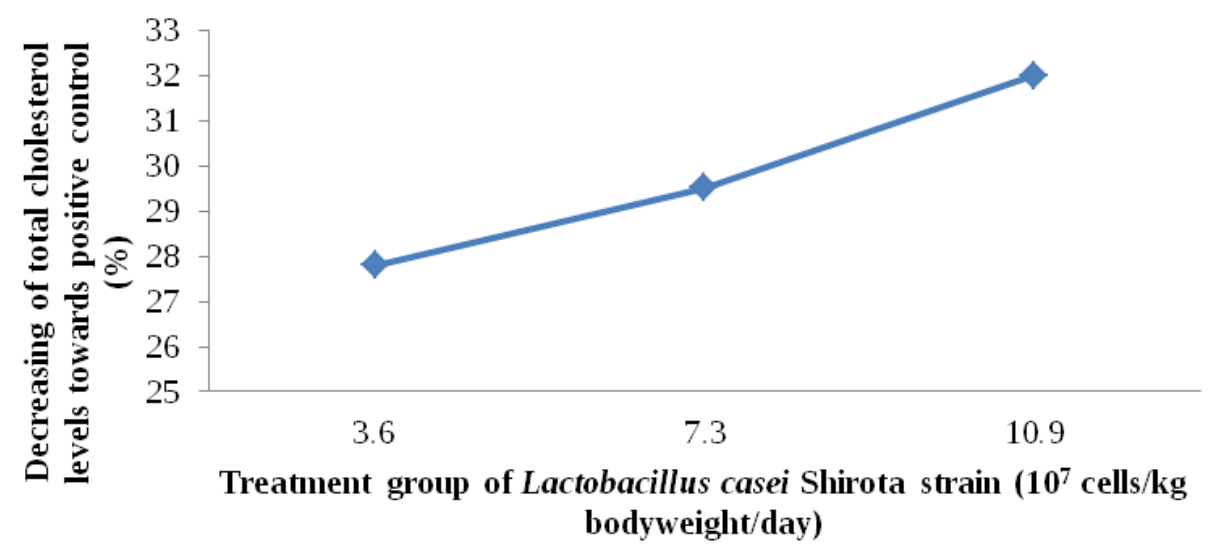

Figure 2. Decreasing of total cholesterol levels after treatmen by probiotic of Lactobacillus casei Shirota strain 
Therapy group that were treated with probiotic of Lactobacillus casei Shirota strain $10.9 \times 10^{7}$ cells $/ \mathrm{kg}$ bodyweight/day had the best total cholesterol levels wich is $55,2 \mathrm{mg} / \mathrm{dL}$ with a decreasing of $32.0 \%$. Dereasing of total cholesterol levels can be seen in Figure 2. This results showed that the probiotic of Lactobacillus casei Shirota strain can decrease the total cholesterol levels. This is in accordance with Yuniastuti (2004) that the provision of fermented milk of Lactobacillus casei Shirota strain capable to lowering total cholesterol, triglyceride levels and LDL cholesterol levels significantly. Kumar, Grover, \& Kumar (2010) showed that, supplementation of the diet with $L$. plantarum Lp91 can significant reduction in plasma total cholesterol $23.26 \%$.

Probiotic bacteria can reduce the total cholesterol levels of blood serum in a variety of ways, include increasing the excretion of bile acids, with deconjugating the bile acids by BSH (Bile Salt Hydrolase) enzyme from probiotic mechanism (Yuliana, 2012). In the other hand, cholesterol assimilation is done by the probiotic directly. In the mechanism of cholesterol assimilation, lactic acid bacteria will take cholesterol from the intestine and incorporate with cellular membrane of bacteria, so the bacteria will more resistant to lysis (Yuniastuti, 2004). Cholesterol was bound to bacterial cells and this was a result of the chemical and structural properties of their cell wall peptidoglycans (Kimoto-Nira et al., 2007). The decreasing of cholesterol absorbed in the intestine bringin on the decreasing of blood cholesterol levels.
Lactobacillus acidophilus were able to assimilate cholesterol by $48,45 \mu \mathrm{g} / \mathrm{mL}$ (Tamaro-duschesneau et al., 2014). In addition, another mechanism of cholesterol reduction by bacteria can be done by converting cholesterol into coprostanol. Lye, Rusul, \& Liong (2010) the results showed that cholesterol levels were decreased in medium due to fermentation by probiotic bacteria followed by increased coprostanol. Some of these mechanisms may work together to lowering cholesterol levels.

\section{Superoxide dismutase (SOD) activity in aortic tissue}

The statistical analysis results with One Way ANOVA showed that probiotic therapy with Lactobacillus casei Shirota strain with dose variation of $3.6 \times 10^{7}, 7.3 \times 10^{7}$ and 10.9 x $10^{7}$ cells $/ \mathrm{kg}$ bodyweight/day can increase the activity of SOD by showed extremely significant differences among the treatments $(p<0.01)$. The results of SOD activity in rats' aorta can be seen in Figure 3.

In Group positive control, the rats experienced a decreasing activity of SOD by $38.16 \%$ compared to the negative control group. The low activity of SOD in the positive control group is due to the high-cholesterol diet which has an effect on the increasing of free radicals in the body exceed the body's capacity to avoid them. The high production of ROS in the body can caused a decreasing of SOD. Dianita, Jantan, Jalil, \& Amran (2016) suggested that the hypercholesterolemic status has triggered oxidative stress as indicated by a significant decrease of serum SOD.

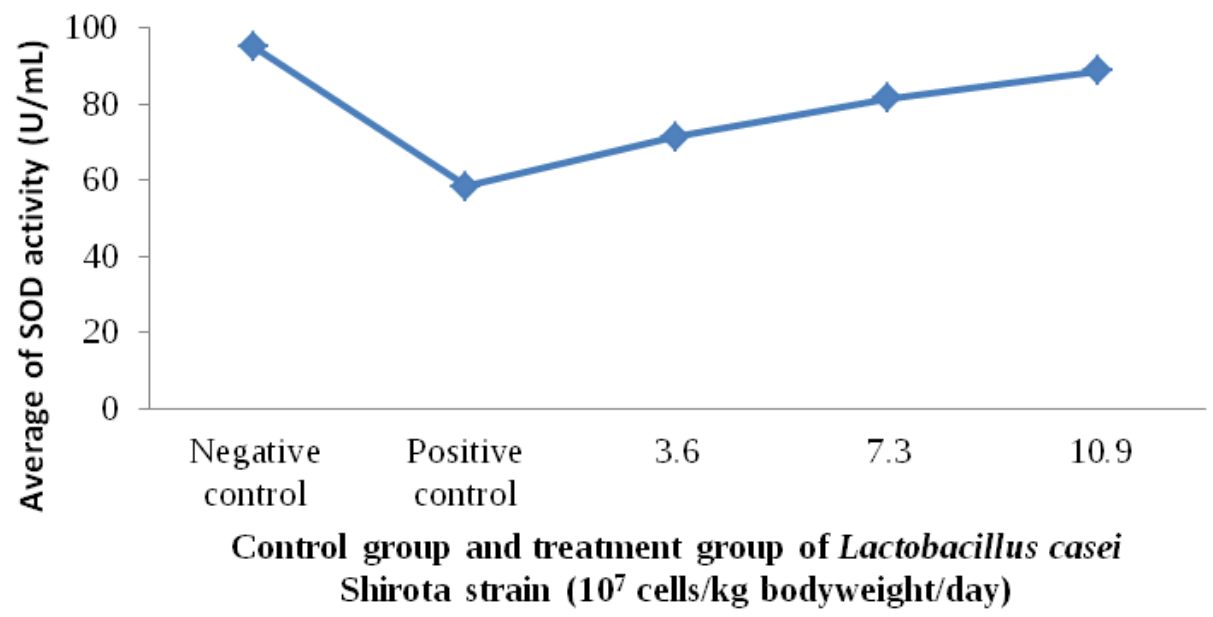

Figure 3. The result of SOD activity in rats' aorta with high cholesterol diet and after by probiotic of Lactobacillus casei Shirota strain 


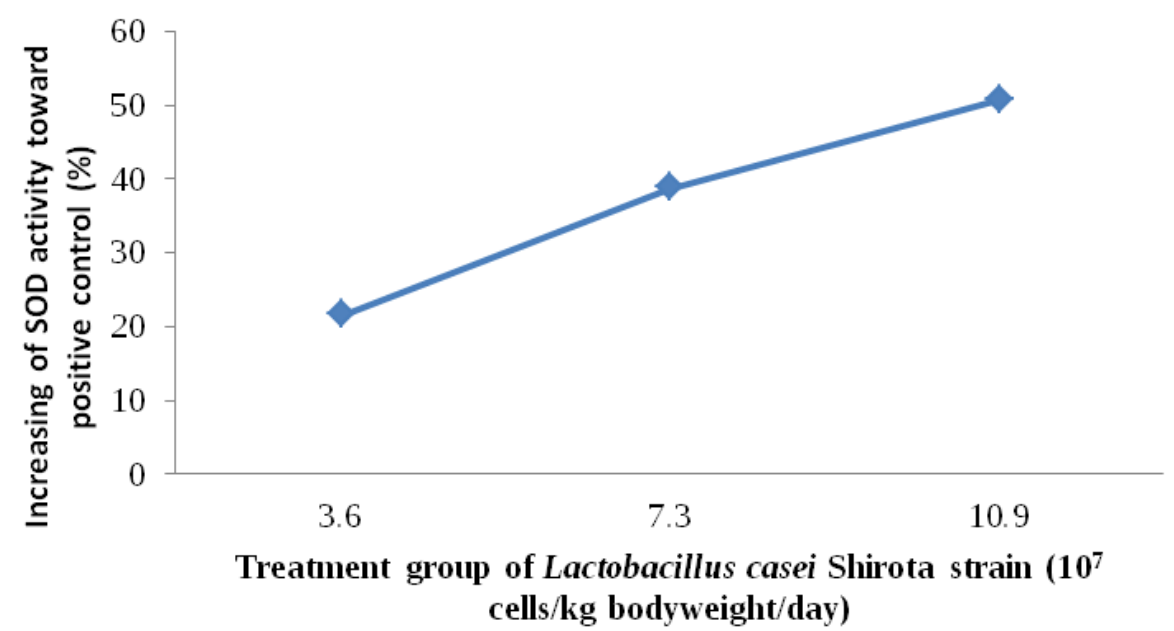

Figure 4. Increasing of SOD activity after treatmen by probiotic of Lactobacillus casei Shirota strain

The highest increasing percentage of SOD activity is $50,70 \%$ in the treatment group with a dose of 10.9 x $10^{7}$ cells $/ \mathrm{kg}$ bodyweight/day. The result of decreasing activity of SOD can be seen in Figure 4. Increasing of SOD activity is due to the probiotic of Lactobacillus casei Shirota strain that containing bioactive peptides as an antioxidant. Sari, Kusrahayu, \& Al-baarri (2014) One of the bioactive components that naturally present in milk is lactoferrin compound. The result of SDS-PAGE in skim milk showed the presence of lactoferin compounds that is in molecular weight range of $80 \mathrm{kDa}$.

The mechanism of lactoferrin as an antioxidant protein is iron binding. Iron ion in certain circumstances can participate in the form Fenton reaction, which can generate ROS (hydroxyl radical) that are very reactive (Moradian, 2014).

The highest value of SOD activity is negative control and the lowest is positive control. The three treatment groups were slightly increased. The treatment group in 10.9 x $10^{7}$ cells $/ \mathrm{kg}$ bodyweight/day of dose therapy showed that the SOD activity had the highest value than the other treatment groups. In addition, the probiotic of Lactobacillus casei Shirota strain therapy can increase the activity of SOD.

\section{CONCLUSION}

Probiotic of Lactobacillus casei Shirota strain therapy has an ability to decrease the blood cholesterol levels and increase the SOD activity in aorta of rats that fed with a highcholesterol diet.

\section{REFERENCES}

Bayatmakoo, R., Rashtchizadeh, N., Yaghmaei, P., Farhoudi, M., \& Karimi, P. (2017). Thymol decreases apoptosis and carotid inflammation induced by hypercholesterolemia through a discount in oxidative stress. Crescent Journal of Medical and Biological Science, 4(4), 186-193.

Bogoriani, N. W. \& Ketut, R. (2015). Efek berbagai minyak pada metabolisme kolesterol terhadap tikus wistar. Jurnal Kimia, 9, 53-60.

Dewi, A. B. F. K. (2009). Menu sehat 30 hari untuk hiperkolesterol, hipertensi, dan penyakit jantung. Jakarta: PT. Agro Media Pustaka.

Dianita, R., Jantan, I., Jalil, J., \& Amran, A. Z. (2016). Phytomedicine Effects of Labisia pumila var alata extracts on the lipid profile, serum antioxidant status and abdominal aorta of high-cholesterol diet rats. Phytomedicine, 23(8), 810817. http://doi.org/10.1016/j.phymed.2016.04 .004

Harini, M., \& Astirin, O. P. (2009). Blood cholesterol levels of hypercholesterolemic rat (Rattus norvegicus) after VCO treatment. Nusantara Bioscience, I(2), 53-58.

http://doi.org/10.13057/nusbiosci/n0102 01

Indonesia Nation Stadardization (SNI). (2009). Yogurt. Jakarta: National Standardization Corporation (BSN).

Kimoto-Nira, H., Mizumachi, K., Nomura, M., 
Kobayashi, M., Fujita, Y., Okamoto, T., Suzuki, I., Tsuji, N. M., Kurisaki, J. I., \& Ohmomo, S. (2007). Lactococcus sp. as potential probiotic lactic acid bacteria. Japan Agricultural Research. Quarterly, 41, 181-189.

Kumar, R., Grover, S., \& Kumar, V. (2010). Hypocholesterolaemic effect of dietary inclusion of two putative probiotic bile salt hydrolase producing Lactobacillus Plantarum strains in sprague-dawley rats. British Journal of Nutrition, 1-12.

Lye, H. S., Rusul, G., \& Liong, M.T. (2010). Removal of cholesterol by Lactobacilli via incorporation of and conversion to coprostanol. Journal of Dairy Science, 93, 1383-1392.

Moradian, F. (2014). Lactoferrin, Isolation, Purification and Antimicrobial Effects. Journal of Medical and Bioenginering, 3(3), 203-206. http://doi.org/10.12720/jomb.3.3.203206

Ooi, G. L. \& Liong, T. M. (2010). Cholesterollowering effects of probiotics and prebiotics: A review of in vivo and in vitro Findings. International Journal of Molecular Sciences, ISSN 1422-0067 Malaysia, 2499-2522.

Rastini, E. K., Widodo, M. A., \& Rohman, M. S. (2010). Pengaruh pemberian ekstrak buah mengkudu (Morinda citrifolia L.) terhadap ekspresi NF-k $\beta$ dan ekspresi protein (TNF- $\alpha$, ICAM-1) pada kultur sel endotel (HUVECs) dipapar OxLDL.
The Journal of Experimental Life Science, 1, (1). ADDIN Mendeley Bibliography CSL_BIBLIOGRAPHY

Sari, C. S., Kusrahayu, K., \& Al-baarri, A. N. (2014). Imobilisasi Komponen Bioaktif Susu dengan Menggunakan Resin. Aplikasi Teknologi Pangan, 3(1), 26-31.

Sujono., Bekti, Y., Hikmawan., \& Yuananda. (2016). Effec of Goat Milk Yogurt towards Reducing Uric acid, Cholesterol, and Blood Glucose Level. International Jurnal of Applied Environmental Science, ISSN 09736077, 11 (5), 1189-1197.

Tomaro-duchesneau, C., Jones, M. L., Shah, D., Jain, P., Saha, S., \& Prakash, S. (2014). Cholesterol Assimilation by Lactobacillus Probiotic Bacteria: An In Vitro Investigation. Biomed Research International, 2014, 9. http://dx.doi.org/10.1155/2014/380316

Towil, A. S., \& Pramono, A. (2014). Pengaruh pemberian yoghurt sinbiotik tanpa lemak ditambah tepung gembili terhadap kadar kolesterol LDL tikus hiperkolesterolemia. Jurnal Gizi Indonesia, 135140.

Yuliana, D. 2012. Kajian mekanisme hipokolesterolemik probiotik. Majalah farmasi dan farmakologi, 12 (2), 95-98.

Yuniastuti, A. (2004). Pengaruh pemberian susu fermentasi Lactobacillus casei strain Shirota terhadap perubahan kadar fraksi lipid serum tikus heperkolesterolemi. Thesis. Biomedic Faculty, Diponegoro University. 